\title{
Effect of potassium fertilizer, feldspar rock and potassium releasing bacterium (Bacillus circulans) on sweet potato plant under sandy soil conditions
}

\author{
*Shimaa Kh.H. Hasan ${ }^{1}$ and A. A. M. Ragab ${ }^{2}$ \\ ${ }^{1}$ Horticulture Research Institute (HRI), ${ }^{2}$ Soil, Water and Environment Research Institute, Agriculture \\ Research Center (ARC), Egypt. \\ *Corresponding Author e-mail :shimaakhamis2000@yahoo.com
}

Received on: 1/9/2020

Accepted on: 30/10/2020

\begin{abstract}
The current study was executed in a newly reclaimed sandy soil at Ali Moubark Farm, South Tahrir Research Station, Horticulture Research Institute, during the two successive growing seasons of 2018-2019, to rationalizing mineral potassium consumption using alternative natural sources like feldspar rock (soluble form) inoculation with potassium releasing bacteria and its impact on production, quality and storability of sweet potato cv. Abees. A randomized complete block design with four replications was used. Treatments $(n=6)$ included four levels of potassium sulphate $(\mathrm{KS})\left(48 \% \mathrm{~K}_{2} \mathrm{O}\right)$ at 25,50 and $75 \%$ of recommended dose (RD) plus feldspar rock (FR) (10.6\% $\mathrm{K}_{2} \mathrm{O}$ ) with inoculation by potassium releasing bacteria (KRB), i.e. Bacillus circulans as well as RD of potassium fertilizer and feldspar rock (singly or combined with KRB).

Results concluded that adding $50 \%$ from the RD of KS plus $50 \%$ FR with inoculation with KRB had significant effects on vegetative growth, (plant length per plant, number of branches per plant, leaf area and chlorophyll content) total yield, yield properties (tuber root diameter, tuber root weight, tuber root length and tuber root dry matter) and chemical constituents (leaves potassium \%, tuber roots total carbohydrate $\%$ and tuber roots potassium $\%$ ). Moreovere, the same treatment had significant negative effects on available soil potassium content, tuber roots weight loss percentage at 30, 60, 90 days after storage and tuber roots decay percentage after storage under ambient temperature. Using $100 \%$ FR had reduction effects on all studied criteria except available soil potassium content, tuber roots weight loss percentage at 30,60, 90 days after storage and tuber roots decay percentage after storage.

Conclusively, the combined application of $\mathrm{KS}\left(100 \mathrm{~kg} \mathrm{fed}^{-1}\right)$, FR $\left(453 \mathrm{~kg} \mathrm{fed}^{-1}\right)$ and inoculation with KRB in sweet potato fields, can be recommended to improve the vegetative growth characters, yield, quality, chemical composition and storability of sweetpotato than the commercial potassium fertilizer (200 $\left.\mathrm{kg} \mathrm{fed}^{-1}\right)$ as well as maximizing the utilization of the natural resources available in the Egyptian environment and minimizing the environmental impact of chemical fertilizers.
\end{abstract}

KEYWORDS: Sweet potato, potassium sulphate, feldspar rock, potassium releasing bacteria and sandy soil

\section{INTRODUCTION}

Sweet potato (Ipomoea batatas (L.) Lam.) is a member of convolvulaceae family. It considered as tuberous root vegetable crop which grown in the tropical, sub-tropical and frost-free temperate climatic zones of the world and consumed by humans and livestock. In Egypt, it is considered a very important popular vegetable crop, it has been generally cultivated for both food and starch manufactures, while the foliage parts and other waste parts are utilized in feeding. Great efforts have been directed to improve sweet potato production and quality for the purpose of increasing exported yield (El-Seifi, et.al., 2014).

Potassium has a significant role in all processes needed to plant growth and reproduction such as translocation of photosynthesis, protein synthesis, control of ionic balance, stress tolerance and water use, activation of more than 60 enzymes and many other processes (Christian et al., 2014). Moreover, K-chemical fertilizers as potassium sulphate contributes in environmental pollution in addition its high price increase production cost.

Whereas, the use of natural potassium fertilizer as feldspar rock is low cost resources for providing plants with $\mathrm{K}$ which could alternates the expensive applied K-chemical fertilizers (Labib et al., 2012).

The use of potassium releasin bacteria as bio-fertilizer was suggested as a sustainable solution to improve plant growth, nutrition, root growth and responses to external stress factors (Priyanka and Sindhu, 2013). Moreover, bio-fertilizer play an important role in the formation of humus in soil and 
the cycling of other minerals tied up in organic matter (Zakaria, 2009). Also, it can able to solubilize rock - K powder, such as feldspar through plant production and excretion of soil organic acids or chelate silicon ions to bring $\mathrm{K}$ into solution (Bennett et al., 1998). On the other hand, soil inoculation with potassium releasing bacteria and the soil feldspar was applied solo or integrated might provide faster and continuous supply of $\mathrm{K}$ for improved plant growth, yield and its quality (Abou-el-Seoud, 2012). Finaly, biofertilization is alternative method for fertilization of most plants. Moreover, the biofertilization minimize the addition of inorganic chemical fertilizers and reduced the hazared effects of chemical fertilizers on human health and environment (Salah et al., 2020).

Therefore, the target of this research work was to rationalizing mineral potassium production consumption by using natural sources such as feldspar rock inoculated with potassium-release bacteria and its impact on production, quality and storability of sweet potato.

\section{MATERIALS AND METHODS}

The current experience was executed in a newly reclaimed sandy soil at Ali Moubark Farm, South Tahrir Research Station, Horticulture Research Institute, during the two successive growing seasons of 2018-2019.

Rationalizing mineral potassium consumption by using natural sources such as feldspar rock inoculated with potassium-release bacteria were applied on sweet potato (Ipomoea batatas L.) cv. Abees plants and its impact on production, quality and root storability were studied.

The main physical and chemical analysis of the tested soil (Table 1) was determined according to Jackson (1973).

Table 1. Physical and chemical analysis of the soil at experimental field $(0-30 \mathrm{~cm})$ depth in 2018 season.

Stem cuttings, about $20 \mathrm{~cm}$ length, were planted on two lines (70 $\mathrm{cm}$ apart) on the ridges $(25$ $\mathrm{cm}$ apart between stem cuttings), in 10/5/2018 and 26/5/2019. The plot area was $10 \mathrm{~m}^{2}(1 \mathrm{~m}$ width X 10 $\mathrm{m}$ length $\mathrm{X} 1$ row). A randomized complete block design with four replications was used. Other agricultural practices were carried out as recommended for the conventional sweet potato planting.

The experiment included 6 treatments as follows

1. Recommended dose of potassium sulphate (KS) $(100 \%)$ cosidered as control treatment.

Table 2. Some chemical constitution of feldspar used in the experiment during 2018-2019 seasons.

\begin{tabular}{|c|c|c|c|c|c|}
\hline \multicolumn{2}{|c|}{ Components } & \multicolumn{2}{|c|}{ Components } & \multicolumn{2}{|c|}{ Components } \\
\hline $\mathbf{A l}_{2} \mathbf{O}_{2}$ & $15.12 \%$ & $\mathrm{Fe}_{2} \mathrm{O}_{2}$ & $0.08 \%$ & $\mathrm{TiO}_{2}$ & $0.01 \%$ \\
\hline $\mathrm{K}_{2} \mathrm{O}$ & $10.6 \%$ & $\mathbf{P}_{2} \mathbf{O}_{2}$ & $0.05 \%$ & $\mathrm{MnO}_{2}$ & $0.02 \%$ \\
\hline MgO & $7.03 \%$ & $\mathrm{CaO}$ & $0.36 \%$ & $\mathrm{CaCO}_{3}$ & $0.42 \%$ \\
\hline $\mathrm{Na}_{2} \mathrm{O}$ & $1.91 \%$ & Cl & $0.03 \%$ & $\mathrm{SiO}_{2}$ & $64.37 \%$ \\
\hline pH & 8.21 & $\operatorname{EC}\left(\mathrm{dS} \mathrm{m}^{-1}\right)$ & 0.55 & & \\
\hline
\end{tabular}

The source of $\mathrm{K}_{2} \mathrm{O}$ was potassium sulphate Bacillus circulans bacteria at a concentration of $\left(48 \% \mathrm{~K}_{2} \mathrm{O}\right)$ and the recommend rate is $96 \mathrm{~kg} / \mathrm{fed}$.

Potassium sulphate were equally divided two portions and applied before planting and 30 days later, while, feldspar rock $\left(10.6 \mathrm{~K}_{2} \mathrm{O}\right)$ was added during soil preparation. Bio-fertilizer contains

2. Feldspar rock (FR) (100\%).

3. FR $(100 \%)+$ potassium releasing bacteria (KRB).

4. $\operatorname{FR}(75 \%)+\mathrm{KS}(25 \%)+\mathrm{KRB}$.

5. $\mathrm{FR}(50 \%)+\mathrm{KS}(50 \%)+\mathrm{KRB}$.

6. $\mathrm{FR}(25 \%)+\mathrm{KS}(75 \%)+\mathrm{KRB}$.

Feldspar rock as a natural local potassium rock powder (soluble form) was produced by $\mathrm{Al}$ Ahram for mining Co., Ltd., Egypt. The chemical properties of the used feldspar rock according to Soltanpour et al. (1996) are presented in Table 2. $\left(5 \times 10^{-1} \mathrm{cfu}\right)$, provided by the unit of bio-fertilizer, Fac. Agric., Ain Shams University. It was applied three times during the cultivation season at the root absorption zone of plants, (adding soil). The first 
was after 21 days from germination and then two times 21 days interval.

\subsection{Measurements}

\subsubsection{Vegetative growth}

Five plants were taken randomly from each plot after 105 days from planting to record the average of following data:

1. Plant length $(\mathrm{cm})$.

2. Number of branches/ plant.

3. Leaf chlorophyll content was measured in the fresh fifth top fully leaf. (A digital Chlorophyll meter, model Minolta Chlorophyll meter SPAD-502, manufactured by Minolta Company was used). SPAD unit $=10 \mathrm{mg} / 100 \mathrm{~g}$ fresh weight of leaves (Netto et al., 2005).

4. Leaf area/ plant of the $5^{\text {th }}$ top fully leaf (determined using the LI-3100 area meter (LI-COR. Inc. Lincoln, Nebraska, USA)).

\subsubsection{Yield and its components}

At harvesting time (135 days from planting) all plants tuber root of each plot were measured

1. Total yield ton /fed.

2. Tuber root diameter $(\mathrm{cm})$.

3. Tuber root weight $(\mathrm{g})$.
4. Dry matter percentage.

5. Tuber root length $(\mathrm{cm})$

\subsubsection{Chemical}

1. Soil sample was taken after harvesting for each treatment then was determined available potassium $\mathrm{mg} / \mathrm{kg}$ described by Jackson (1973).

2. Potassium (\%) was determined in leaves described by Brown and Lilliland (1946).

3. Samples of tuber root were dried at $70^{\circ} \mathrm{C}$ till constant weight then were used for the chemical determinations and were calculated according dry weight basis.

a. Potassium (\%) described by Brown and Lilliland (1946).

b. Total carbohydrate percentage described by Dubois et al. (1956).

\subsubsection{Tuber root of storage period}

Random samples of cured roots (each $10 \mathrm{~kg}$ of tuber roots) were collected from each plot, cleaned, packed in plastic boxes and stored for 90 days at normal room conditions. The average of normal room temperature and relative humidity during storage months are shown in Table (3).

Table 3. The average of normal room temperature and relative humidity during storage months.

\begin{tabular}{lcccc}
\hline Months & \multicolumn{2}{c}{ Temperature $\left({ }^{\circ} \mathbf{C}\right)$} & \multicolumn{2}{c}{ Relative humidity (\%) } \\
\cline { 2 - 5 } & $\mathbf{2 0 1 8}$ & $\mathbf{2 0 1 9}$ & $\mathbf{2 0 1 8}$ & $\mathbf{2 0 1 9}$ \\
\hline Octobar & 25 & 25.8 & 55.4 & 58.6 \\
November & 23 & 22 & 64.1 & 57.8 \\
December & 17 & 16.8 & 64.4 & 64.7 \\
January & 13.6 & 13.5 & 50.9 & 62.5 \\
\hline
\end{tabular}

- Samples were chosen after 30,60 and 90 days of storage to determine weight loss percentage according to the equation:

Weight loss $(\%)=$ Initial weight of tuber roots weight of tuber roots at sampling date X100

\section{Initial weight of tuber roots}

- Decay: All tubers were inspected in terms of fungal or bacterial infections, decayed tubers were counted and removed. The percentage of decayed tubers was calculated at the end of storage period in relation to the total initial number of stored tubers.

\subsection{Statistical analysis}

All data analyses were performed using the STATISTIX version 8.0 software. The comparisons of treatment means were done with Duncan Multiple Range Test (Duncan, 1955).

\section{RESULTS AND DISCUSSION}

\subsection{Vegetative growth}

Data in Table 4 showed that the effect of potassium sulphate doses and feldspar rock + inoculated potassium releasing bacteria on plant growth parameters (plant length per plant, number of branches per plant, leaf area and chlorophyll content). It is obvious that, potassium fertilizer treatements had enhancing effect on all studied morphological characters of sweet potato plants. Application 50\% potassium sulphate (KS) plus 50\% feldspar rock (FR) with inoculation by KRB followed by addtion $75 \% \mathrm{KS}$ plus $25 \%$ FR with inoculation by KRB gave the highest values of plant length per plant, number of branches per plant, leaf area and chlorophyll content, while the lowest values were obtained when application $100 \%$ FR $(10.6 \mathrm{~kg} /$ fed.) preceded it adding $100 \%$ FR with inoculation by KRB were used during the two seasons.

In this respect, the superiority of plant growth might be attributed to the availability and speed solubility of chemical potassium form and this reflect on its role in cell multiplication and photosynthesis in conjunction with $\mathrm{N}$, which gave rise to increase in length of vine, number of leaves and branches, this consequently gave heavier dry weight of vine (Trehan et al., 2009). The recorded data pointed that feldspar wasn't enough source of $\mathrm{K}$ 
Table 4. Effect of potassium sulphate doses and feldspar rock with inoculated potassium releasing bacteria on vegetative growth of sweet potato (Abees) during 2018 and 2019 seasons.

\begin{tabular}{|c|c|c|c|c|c|c|c|c|}
\hline \multirow[t]{2}{*}{ Treatments } & \multicolumn{2}{|c|}{$\begin{array}{c}\text { Plant } \\
\text { length }(\mathrm{cm})\end{array}$} & \multicolumn{2}{|c|}{$\begin{array}{c}\text { Branch } \\
\text { number/ } \\
\text { plant }\end{array}$} & \multicolumn{2}{|c|}{$\begin{array}{c}\text { Leaf area } \\
\left(\mathrm{cm}^{2} / \text { plant }\right)\end{array}$} & \multicolumn{2}{|c|}{$\begin{array}{c}\text { Chlorophyll } \\
\text { content (SPAD) }\end{array}$} \\
\hline & 2018 & 2019 & 2018 & 2019 & 2018 & 2019 & 2018 & 2019 \\
\hline $100 \%$ FR $^{*}$ & $124.3 \mathrm{D}$ & $144.0 \mathrm{D}$ & $6.0 \mathrm{D}$ & $8.6 \mathrm{E}$ & 192.6D & $243.0 \mathrm{E}$ & $39.9 \mathrm{D}$ & $43.4 \mathrm{D}$ \\
\hline $100 \% \mathrm{KS}^{* *}$ & 157.0AB & 161.6BC & $8.3 \mathrm{~B}$ & $12.3 \mathrm{C}$ & 296.6B & 321.3B & $46.5 B$ & 48.5B \\
\hline $100 \% \mathrm{FR}+\mathrm{KRB} * * *$ & $141.6 \mathrm{C}$ & $153.3 \mathrm{CD}$ & $7.3 \mathrm{C}$ & $10.3 \mathrm{D}$ & 195.3D & 268.0D & $44.2 \mathrm{C}$ & $45.6 \mathrm{C}$ \\
\hline $75 \% \mathrm{FR}+25 \% \mathrm{KS}+\mathrm{KRB}$ & 150.0BC & 147.3D & $6.3 \mathrm{D}$ & $11.0 \mathrm{D}$ & $216.3 \mathrm{C}$ & $302.6 \mathrm{C}$ & $45.5 \mathrm{BC}$ & 43.8CD \\
\hline $50 \% \mathrm{FR}+\mathbf{5 0} \% \mathrm{KS}+\mathrm{KRB}$ & $164.0 \mathrm{~A}$ & $176.0 \mathrm{~A}$ & $9.6 \mathrm{~A}$ & $14.3 \mathrm{~A}$ & $323.3 \mathrm{~A}$ & $337.3 \mathrm{~A}$ & 49.9A & $54.0 \mathrm{~A}$ \\
\hline $25 \% \mathrm{FR}+75 \% \mathrm{KS}+\mathrm{KRB}$ & 161.6AB & $171.6 \mathrm{AB}$ & $9.3 \mathrm{~A}$ & $13.3 \mathrm{~B}$ & $313.3 \mathrm{~A}$ & $331.3 \mathrm{AB}$ & $48.8 \mathrm{~A}$ & $52.5 \mathrm{~A}$ \\
\hline
\end{tabular}

Means within the same column followed by the same letters are not significantly different at 5\% according to Duncan's Multiple Range Test.

*FR: feldspar rock, **KS: potassium sulphate, $* * * \mathrm{KRB}$ as potassium releasing bacteria i.e. Bacillus circulans.

to supply grown plant by its requirements due to the fact that potassium ion is tightly bound within its minerals structure and little release appeared to have occurred with its application (Hellal et al., 2009). In this regard such increments in growth parameters due to inoculation with KDB (potassium dissolving bacteria) with potassium sulphate and feldspar might be attributed to the fact that, bacteria can solubilize them and thus provide faster and continuous supply of K for optimal plant growth (Abou-el-Seud, 2012 and Priyanka and Sindhu, 2013). Also, growth enhancement by bacteria may relate to its ability to produce extensive root length and can improve root development and increase the rate of water and mineral uptake (Saghir et al., 2007).

Obtained results are in harmony with those reported by Shams and Wafaa Fekry (2014) and Saif Eldeen and Baddour (2016) on sweet potato, they indicated that, using $50 \%$ potassium sulphate $+50 \%$ feldspar + bio fertilizer recorded maximum values of plant length, number branches/ plant and chlorophyll content.

\subsection{Yield and its components}

Data presented in Tables (5 and 6) represent the effect of potassium sulphate KS doses plus feldspar rock FR + inoculated potassium releasing bacteria KRB on yield and components of sweet potato. Applying plant fertilizer with 50\% KS plus $50 \%$ FR + inoculated by KRB next that fertilizer plants with $75 \% \mathrm{KS}$ plus $25 \%$ FR with inoculation by KRB increased sweet potato total yield (ten/ fed.), tuber root diameter, tuber root weight, tuber root length and tuber root dry matter. The applying fertilizer with $100 \%$ FR alone recorded the lowest values of the same previously mentioned traits in both seasons. These results may be due to that potassium could be directly linked to the welldeveloped photosynthetic surfaces and increased physiological activities leading to more assimilates being produced and subsequently translocate and utilized in rapid tuber development and production. Moreover, Habibi et al. (2011) strongly suggested that using biofertilizers plus half dose of feldspar and chemical fertilizers have resulted in the greatest yield. They revealed that $50 \%$ of required potassium fertilizer could be replaced by bio and feldspar fertilizers, because bio and feldspar fertilizers improved the efficiency use of recommended potassium fertilizer and reduced the cost of chemical fertilizer, also reduced the environment pollution from extensive application of chemical fertilizer. These results are in agreement with Shams and Wafaa Fekry (2014) and Saif Eldeen and Baddour (2016) on sweet potato, they stated that using 50\% potassium sulphate $+50 \%$ potassium feldspar and biofertilizer gave the best yield and it's component.

\subsection{Chemical}

Advanced results in Tables (6 and 7) introduced that the applying of potassium sulphate doses and feldspar rock + inoculated potassium releasing bacteria on chemical analysis of sweet potato had a significant effect. It is showed that plants fertilized with $50 \% \mathrm{KS}$ plus $50 \%$ FR with inoculation by KRB gave the higest results for leaves potassium percentage, tuber roots total carbohydrate $\%$ and tuber roots potassium $\%$ as well as recorded the lowest results for available soil potassium content. The lowest results noticed with plants fertilized by $100 \%$ FR for the leaves potassium percentage, tuber roots total carbohydrate $\%$ and tuber roots potassium $\%$ as well as showed the higest results for available soil potassium content. The addition of FR only, showed low obtained chemical compostion of sweet potato. This can be explained by the slow and long release of $\mathrm{K}$ from $\mathrm{FR}$ through stages of growth (Labib et al., 2012). These results agreeded with Labib et al. (2012) on potato, Shams and Fekry (2014) and Saif Eldeen and Baddour (2016) on 
Table 5. Effect of potassium sulphate doses and feldspar rock with inoculated potassium releasing bacteria on yield and components of sweet potato (Abees) during 2018 and 2019 seasons.

\begin{tabular}{|c|c|c|c|c|c|c|c|c|c|}
\hline \multirow{2}{*}{\multicolumn{2}{|c|}{ Treatments }} & \multicolumn{2}{|c|}{$\begin{array}{c}\text { Total yield } \\
\text { (ton/ fed.) }\end{array}$} & \multicolumn{2}{|c|}{$\begin{array}{c}\text { Tuber root } \\
\text { diameter }(\mathbf{c m})\end{array}$} & \multicolumn{2}{|c|}{$\begin{array}{l}\text { Tuber root } \\
\text { weight (g) }\end{array}$} & \multicolumn{2}{|c|}{$\begin{array}{l}\text { Tuber root } \\
\text { length }(\mathrm{cm})\end{array}$} \\
\hline & & 2018 & 2019 & 2018 & 2019 & 2018 & 2019 & 2018 & 2019 \\
\hline $100 \% \mathrm{FR}^{*}$ & & $6.133 \mathrm{E}$ & $9.033 \mathrm{E}$ & $3.7 \mathrm{D}$ & $4.8 \mathrm{D}$ & $237.7 \mathrm{C}$ & $246.0 \mathrm{D}$ & $11.6 \mathrm{E}$ & $15.3 \mathrm{C}$ \\
\hline $100 \% \mathrm{KS}^{* *}$ & & $12.800 \mathrm{~B}$ & $15.167 \mathrm{~B}$ & $5.4 \mathrm{~B}$ & $6.3 \mathrm{AB}$ & $366.1 \mathrm{~A}$ & $280.3 \mathrm{~B}$ & $17.0 \mathrm{~B}$ & $20.0 \mathrm{~A}$ \\
\hline $100 \% \mathrm{FR}+\mathrm{KRB} * * *$ & & $7.800 \mathrm{D}$ & $12.933 \mathrm{D}$ & $4.2 \mathrm{C}$ & $5.4 \mathrm{C}$ & $253.3 \mathrm{C}$ & $251.6 \mathrm{D}$ & $13.6 \mathrm{D}$ & $16.3 \mathrm{BC}$ \\
\hline $\begin{array}{ll}75 \% & \text { FR+25\%KS } \\
\text { KRB } & \end{array}$ & + & $10.833 \mathrm{C}$ & $14.100 \mathrm{C}$ & $4.7 \mathrm{C}$ & $6.0 \mathrm{~B}$ & 279.3B & $263.1 \mathrm{C}$ & $15.3 \mathrm{C}$ & $17.6 \mathrm{~B}$ \\
\hline $\begin{array}{ll}\mathbf{5 0 \%} & \text { FR+50\% KS } \\
\text { KRB } & \end{array}$ & + & $14.300 \mathrm{~A}$ & $16.533 \mathrm{~A}$ & $6.0 \mathrm{~A}$ & $6.8 \mathrm{~A}$ & $280.6 \mathrm{~A}$ & $290.8 \mathrm{~A}$ & $18.3 \mathrm{~A}$ & $21.3 \mathrm{~A}$ \\
\hline $\begin{array}{ll}25 \% & \text { FR+75\% KS } \\
\text { KRB } & \end{array}$ & + & $13.333 \mathrm{AB}$ & $15.800 \mathrm{AB}$ & $5.9 \mathrm{AB}$ & $6.6 \mathrm{~A}$ & $375.5 \mathrm{~A}$ & $284.9 \mathrm{AB}$ & $17.6 \mathrm{AB}$ & $20.6 \mathrm{~A}$ \\
\hline
\end{tabular}

Means within the same column followed by the same letters are not significantly different at 5\% according to Duncan's Multiple Range Test

*FR: feldspar rock, **KS: potassium sulphate, ${ }^{* * * K R B}$ as potassium releasing bacteria i.e. Bacillus circulans

Table 6. Effect of potassium sulphate doses and feldspar rock with inoculated potassium releasing bacteria on tuber root dry matter and chemical of sweet potato (Abees) during 2018 and 2019 seasons.

\begin{tabular}{lllllllll}
\hline Treatments & \multicolumn{2}{c}{$\begin{array}{c}\text { Tuber root dry } \\
\text { matter \% }\end{array}$} & \multicolumn{2}{c}{$\begin{array}{c}\text { available soil } \\
\text { potassium } \\
\mathbf{m g} / \mathbf{~ k g}\end{array}$} & \multicolumn{2}{c}{$\begin{array}{c}\text { Leaves } \\
\text { potassium \% }\end{array}$} & \multicolumn{2}{c}{$\begin{array}{c}\text { Tuber root total } \\
\text { carbohydrate \% }\end{array}$} \\
\hline & $\mathbf{2 0 1 8}$ & $\mathbf{2 0 1 9}$ & $\mathbf{2 0 1 8}$ & $\mathbf{2 0 1 9}$ & $\mathbf{2 0 1 8}$ & $\mathbf{2 0 1 9}$ & $\mathbf{2 0 1 8}$ & $\mathbf{2 0 1 9}$ \\
\hline $\mathbf{1 0 0 \%}$ FR* & $18.8 \mathrm{D}$ & $16.1 \mathrm{E}$ & $82.7 \mathrm{~A}$ & $76.7 \mathrm{~A}$ & $1.23 \mathrm{E}$ & $1.17 \mathrm{D}$ & $63.9 \mathrm{C}$ & $69.2 \mathrm{C}$ \\
$\mathbf{1 0 0 \%} \mathbf{K S} * *$ & $25.8 \mathrm{~B}$ & $25.1 \mathrm{BC}$ & $64.0 \mathrm{C}$ & $61.4 \mathrm{CD}$ & $1.41 \mathrm{C}$ & $1.28 \mathrm{~B}$ & $69.6 \mathrm{AB}$ & $73.5 \mathrm{~B}$ \\
$\mathbf{1 0 0 \%} \mathbf{F R}+\mathbf{K R B} * * *$ & $20.1 \mathrm{CD}$ & $19.6 \mathrm{D}$ & $76.4 \mathrm{~B}$ & $71.4 \mathrm{AB}$ & $1.30 \mathrm{DE}$ & $1.19 \mathrm{CD}$ & $65.9 \mathrm{C}$ & $71.1 \mathrm{BC}$ \\
$\mathbf{7 5 \%} \mathbf{F R + 2 5 \% ~ K S}+\mathbf{K R B}$ & $22.3 \mathrm{C}$ & $22.9 \mathrm{C}$ & $72.3 \mathrm{C}$ & $67.3 \mathrm{BC}$ & $1.36 \mathrm{CD}$ & $1.24 \mathrm{BC}$ & $68.9 \mathrm{~B}$ & $72.8 \mathrm{~B}$ \\
$\mathbf{5 0 \%} \mathbf{F R + 5 0 \%} \mathbf{K S}+\mathbf{K R B}$ & $29.1 \mathrm{~A}$ & $28.9 \mathrm{~A}$ & $55.7 \mathrm{~F}$ & $46.8 \mathrm{E}$ & $1.62 \mathrm{~A}$ & $1.38 \mathrm{~A}$ & $71.9 \mathrm{~A}$ & $78.5 \mathrm{~A}$ \\
$\mathbf{2 5 \%} \mathbf{F R + 7 5 \%} \mathbf{K S}+\mathbf{K R B}$ & $27.0 \mathrm{~B}$ & $26.9 \mathrm{AB}$ & $61.9 \mathrm{E}$ & $58.0 \mathrm{D}$ & $1.51 \mathrm{~B}$ & $1.29 \mathrm{~B}$ & $70.2 \mathrm{AB}$ & $78.0 \mathrm{~A}$
\end{tabular}

Means within the same column followed by the same letters are not significantly different at 5\% according to Duncan's Multiple Range Test

*FR: feldspar rock, **KS: potassium sulphate, ${ }^{* * * K R B}$ as potassium releasing bacteria i.e. Bacillus circulans

sweet potato, they mention that adding $50 \%$ both from KS and FR with inoculation by KRB recorded the high values for chemical analysis of plant.

\subsection{Tuber root of storage period}

Data presented in Table (7) and figer (1) indicated that adding fertilizer $100 \%$ FR then $100 \%$ FR with inoculation by KRB increased weight loss percentage in tuber roots of sweet potato at 30,60, 90 days during the storage period and tuber roots decay percentage after storage under ambiment temperature condition while, the adding fertilizer $50 \% \mathrm{KS}$ of RD plus $50 \%$ FR inoculation with KRB decreased tuber roots weight loss percentage and tuber roots decay percentage in 2018 and 2019 seasons. These results may be due to that inoculation with Bacillus circulans bacteria reduced the susceptibility of root tissues to the infection of bacterial and fungal diseases as well as best attacks. Also, weight loss may be reduced by developing storage root with better skin and develop flash with more pound water which restricts water loss during the early storage periods (Hassan et al., 2005). These results are in agreement with Saif Eldeen and Baddour (2016) on sweet potato, they mention that the lowest weigth loss \% during the storage period recorded by moderate rate of potassium sulphate of recommended dose plus $50 \%$ K-feldspar inoculation with Bacillus circulans bacteria. 
Table 7. Effect of potassium sulphate doses and feldspar rock with inoculated potassium releasing bacteria on tuber root potassium \% and tuber root weight loss of sweet potato (Abees) stored roots during 2018 and 2019 seasons.

\begin{tabular}{|c|c|c|c|c|c|c|c|c|}
\hline \multirow{3}{*}{ Treatments } & \multirow{2}{*}{\multicolumn{2}{|c|}{$\begin{array}{l}\text { Tuber roots } \\
\text { potassium \% }\end{array}$}} & \multicolumn{6}{|c|}{ Tuber roots weight loss } \\
\hline & & & \multicolumn{2}{|c|}{30 days } & \multicolumn{2}{|c|}{60 days } & \multicolumn{2}{|c|}{90 days } \\
\hline & 2018 & 2019 & 2018 & 2019 & 2018 & 2019 & 2018 & 2019 \\
\hline $100 \% \mathrm{FR}^{*}$ & $2.95 \mathrm{C}$ & $2.25 \mathrm{D}$ & $18.4 \mathrm{~A}$ & $25.0 \mathrm{~A}$ & $26.8 \mathrm{~A}$ & $38.3 \mathrm{~A}$ & $38.7 \mathrm{~A}$ & $47.5 \mathrm{~A}$ \\
\hline $100 \% \mathrm{KS}^{* *}$ & $3.40 \mathrm{~B}$ & $3.00 \mathrm{~B}$ & $14.1 \mathrm{D}$ & $20.0 \mathrm{C}$ & $22.9 \mathrm{C}$ & $31.8 \mathrm{C}$ & $31.7 \mathrm{C}$ & $40.2 \mathrm{D}$ \\
\hline $100 \% \mathrm{FR}+\mathrm{KRB} * * *$ & $3.00 \mathrm{C}$ & $2.67 \mathrm{C}$ & 17.0B & $23.8 \mathrm{~A}$ & $25.5 \mathrm{AB}$ & $37.5 \mathrm{~A}$ & $37.0 \mathrm{AB}$ & $45.5 \mathrm{~B}$ \\
\hline $75 \% \mathrm{FR}+25 \% \mathrm{KS}+\mathrm{KRB}$ & $3.35 \mathrm{~B}$ & $2.67 \mathrm{C}$ & $15.6 \mathrm{C}$ & $22.0 \mathrm{~B}$ & $24.3 \mathrm{~B}$ & $34.7 \mathrm{~B}$ & $35.7 \mathrm{~B}$ & $42.2 \mathrm{C}$ \\
\hline $50 \% \mathrm{FR}+50 \% \mathrm{KS}+\mathrm{KRB}$ & $3.67 \mathrm{~A}$ & $3.20 \mathrm{~A}$ & $10.6 \mathrm{~F}$ & $15.6 \mathrm{D}$ & $19.4 \mathrm{D}$ & $24.5 \mathrm{E}$ & $26.4 \mathrm{E}$ & $31.9 \mathrm{~F}$ \\
\hline $25 \% \mathrm{FR}+75 \% \mathrm{KS}+\mathrm{KRB}$ & $3.60 \mathrm{~A}$ & $3.02 \mathrm{AB}$ & $12.6 \mathrm{E}$ & $18.9 \mathrm{C}$ & $20.6 \mathrm{D}$ & $28.6 \mathrm{D}$ & $28.4 \mathrm{D}$ & $34.1 \mathrm{E}$ \\
\hline
\end{tabular}

Means within the same column followed by the same letters are not significantly different at 5\% according to Duncan's Multiple Range Test

*FR: feldspar rock, **KS: potassium sulphate, ${ }^{* * * K R B}$ as potassium releasing bacteria i.e. Bacillus circulans

Fig. 1. Effect of potassium sulphate doses and feldspar rock with inoculated potassium releasing bacteria on tuber roots decay percentage of sweet potato (Abees) stored roots during 2018 and 2019 seasons.

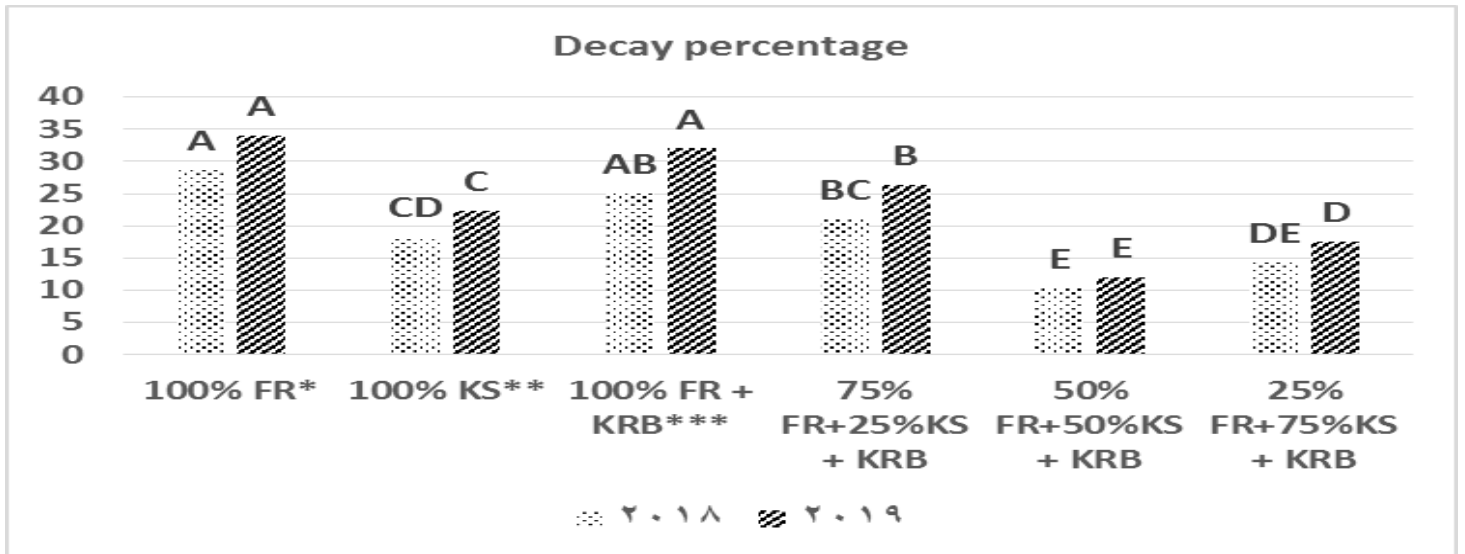

Means within the same column followed by the same letters are not significantly different at $5 \%$ according to Duncan's Multiple Range Test

*FR: feldspar rock, **KS: potassium sulphate, ${ }^{* * *} \mathrm{KRB}$ as potassium releasing bacteria i.e. Bacillus circulans

\subsection{Apendix}

Table 8. Chemical analysis of the soil after harvesting for each treatment at experimental field $(0-30 \mathrm{~cm}$ depth) in mean two seasons 2018-2019.

\begin{tabular}{|c|c|c|c|c|c|c|c|c|c|c|c|c|}
\hline \multirow{2}{*}{$\begin{array}{l}\text { Soil } \\
\text { Treatment }\end{array}$} & \multirow[t]{2}{*}{ PH } & \multirow{2}{*}{$\begin{array}{c}\mathrm{dS} / \mathrm{m} \\
\mathrm{EC}\end{array}$} & \multicolumn{4}{|c|}{ Cations meq/L } & \multicolumn{4}{|c|}{ Anions meq/L } & \multirow[t]{2}{*}{ Sp } & \multirow{2}{*}{$\begin{array}{c}\mathrm{N} \\
\mathrm{Mg} / \mathrm{kg}\end{array}$} \\
\hline & & & $\mathbf{C a}^{2}$ & $\mathbf{M g}^{+2}$ & $\mathbf{N a}^{+}$ & $\mathbf{K}^{+}$ & $\mathrm{CO}_{3}{ }^{--}$ & $\mathrm{HCO}_{3}^{-}$ & CL & $\mathrm{SO}_{4}^{--}$ & & \\
\hline $100 \%$ FR* $^{*}$ & 7.20 & 1.30 & 5.88 & 2.30 & 4.26 & 1.56 & 0.00 & 2.36 & 3.13 & 8.52 & 20.0 & 98.0 \\
\hline $100 \% \mathrm{KS}^{* *}$ & 7.40 & 1.36 & 5.88 & 2.30 & 4.78 & 0.32 & 0.00 & 2.83 & 2.50 & 7.95 & 21.0 & 77.5 \\
\hline $\begin{array}{l}\text { 100\% FR + } \\
\text { KRB**** } \\
75 \%\end{array}$ & 7.50 & 1.34 & 3.92 & 2.44 & 4.78 & 1.27 & 0.00 & 2.83 & 2.50 & 7.08 & 19.0 & 87.5 \\
\hline $\begin{array}{l}\text { FR+25\% KS } \\
+ \text { KRB } \\
50 \%\end{array}$ & 7.30 & 1.26 & 5.88 & 5.03 & 1.52 & 1.31 & 0.00 & 4.25 & 2.50 & 7.00 & 23.0 & 84.0 \\
\hline $\begin{array}{l}\text { FR+50\% KS } \\
+ \text { KRB } \\
25 \% \\
\text { FR+75\% KS }\end{array}$ & 7.50 & 1.20 & 4.90 & 1.46 & 3.74 & 1.48 & 0.00 & 2.36 & 2.50 & 6.72 & 20.0 & 73.5 \\
\hline$+\mathrm{KRB}$ & 7.20 & 1.33 & 5.88 & 3.21 & 4.61 & 0.37 & 0.00 & 2.83 & 2.50 & 8.74 & 19.0 & 73.5 \\
\hline
\end{tabular}


chemical composition and storability of sweetpotato than the commercial potassium fertilizer $\left(200 \mathrm{~kg}^{-}\right.$fed $^{-}$ $\left.{ }^{1}\right)$ as well as maximizing the utilization of the natural resources available in the Egyptian environment and minimizing the environmental impact of chemical fertilizers.

\section{REFERENCES}

Abou-el-Seoud AA (2012). Impact of rock materials and biofertilizations on $\mathrm{P}$ and $\mathrm{K}$ availability for maize (Zea maize) under calcareous soil condition. Saudi Journal of Biological Science, 19: 55-63.

Bennett Pc, Choi WJ, Rogers JR ( 1998). Microbial destruction of feldspars. Mineral Mag., 62(A): 129-150.

Brown JD, Lilliland O (1946). Rapid determination of potassium and sodium in plant material and soil extracts by flame photometry. Proc. Amer. Soc. Hort. Sci., 48: 341-346.

Christian Z, Mehmet S, Edgar Peiterc D (2014). Potassium effect in plants J. of Plant Physiology., 171 (9): 656-669.

Dubois M, Gilles KA, Hamition JK, Rebers PA (1956). Colorimetric method for determination of sugars and related substances. Anal. Chem., 28: 35035 .

Duncan DB (1955). Multiple Range and Multiple FTests. Biometrics.11: 1-42.

El-Seifi SK, Hassan MA, Sawsan Serg MH, Saif El-Deen UM, Mohamed MA (2014). Effect of calcium, potassium and some antioxidants on growth, yield and storability of sweet potato: 2Chemical composition and storability of tuber roots during storage period. Annals of Agric. Sci., Moshtohor 52(1): 91- 110.

Habibi A, Heidari G, Sohrabi Y, Badakhshan H, Mohammadi K (2011). Influence of bio, organic and chemical fertilizers on medicinal pumpkin traits. Journal of Medicinal Plants Research. 5(23): 55905597.

Hassan MA, El-Seifi SK, Omar EA, Saif El-Deen UM (2005). Effect of mineral and bio-phosphate fertilization and quality of sweet potat "Ipomoea batata" L.، 3- Postharvest quality of stored roots. J. Agric. Sci. Mansoura Univ., 30(10): 6183-6196.

Hellal FA, Abd El-Hady M, Ragab AAM (2009). Influence of organic amendments on nutrient availability and uptake by faba bean plants fertilized by rock phosphate and feldspar. Amer-Eurasian J. Agric. \& Environ. Sci., 6 (3): 271-279.
Jackson ML (1973). "Soil chemical analysis" Prentice- Hall, India, Private Limated, New Delhi. 183- 203.

Labib BF, Ghabour TK, Rahim IS, Wahba MM (2012). Effect of potassium bearing rock on the growth and quality of potato crop (Solanum tubersoum). J. Agric. Biotechnology and Sustainable Development, 4 (1): 7-15.

Netto AT, Campostrini EJ, Oliveira G, Bressan SRE (2005). Photosynthetic pigments, nitrogen, chlorophyll a fluorescence and SPAD 502 readings in coffee leaves. Scientia Hort., No. 104:199-209.

Priyanka P, Sindhu SS (2013). Potassium solubilization by rhizosphere bacteria: influence of nutritional and environmental conditions. $\mathrm{J}$. Microbiology Res., 3 (1): 25-31.

Saghir KM, Zaidi A, Wani PA (2007). Role of phosphate-solubilizing microorganisms in sustainable agriculture: a review. Agron. Sustain. Dev. (27): 29-43.

Saif Eldeen UM, Baddour AG (2016). Productivity and storability of sweet potato as influenced by natural, conventional potassium fertilizer sources and silicate dissolving bacteria. Egypt. J. Appl. Sci. 31 (2): 110-119.

Salah GA, Saad OAO, Hassan OHM (2020). Evaluation of biofertilization on growth and quality of moringa oleifera grown on sandy soil. Scientific Journal of Agricultural Sciences 2 (1): 42-49.

Shams AS, Wafaa AF (2014). Efficiency of applied k-feldspar with potassium sulphate and silicate dissolving bacteria on sweet potato plants. Zagazig j. Agric. Res., 41(3): 467- 477.

Soltanpour PN, Johson GW, Jones JR, Miller RO (1996). Inductively coupled plasma emission spectrometry and inductively coupled plasma mass spectromy. Segose Rd., Madison, WI 53711, USA. Chemical Methods. Methods of Soil Analysis, Part 3, Chemical Methods, SSSA Book series, No 5.

Trehan SP, Pandey SK, Bansal SK (2009). Potassium nutrition of potato crops - The Indian Scenario (pp. 2-9).

Zakaria AAB (2009). Growth optimization of potassium solubilizing bacteria isolated from biofertilizer. Bachelor of Cehm. Eng. (Biotech.) Fac. Cehm.Natural Resources Engl. Univ., Malaysia, Pahang, P40. 


\section{الملخص العربى}

\section{تاثير التسميد بالبوتاسيوم وصخر الفلسبار والبكتريا المحررة للبوتاسيوم على نبات البطاطا تحت ظروف الاراضى الرملية}

\section{شيماء خميس حنفى حسن' وعبد العزيز محمد محمد رجب}

$$
\text { 'معهد بحوث البساتين و 'معهد بحوث الاراضى والمياه والبيئة - مركز البحوث الزراعية - جيزه }
$$

أجريت الدراسة الحالية في تربة رملية مستصلحة حديثا بمزرعة علي مبارك بمحطة بحوث جنوب التحرير -معهد بحوث البساتين

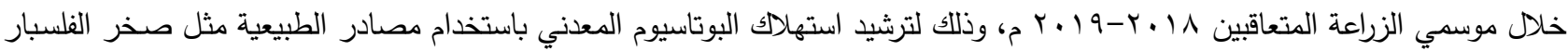

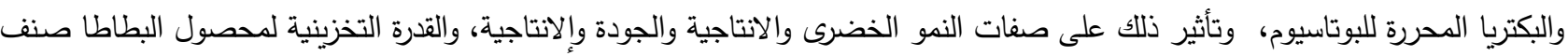

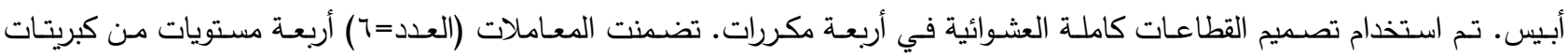

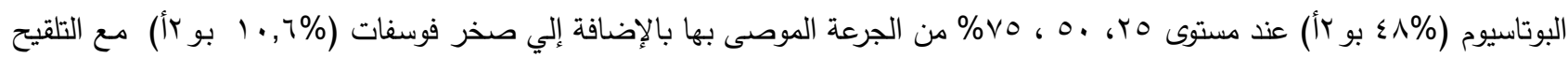

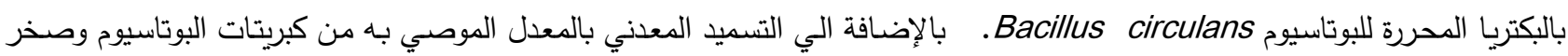
الفلسبار (منفردا او مع التلقيح الميكروبي للبكتيريا المحررة للبوتاسيوم).

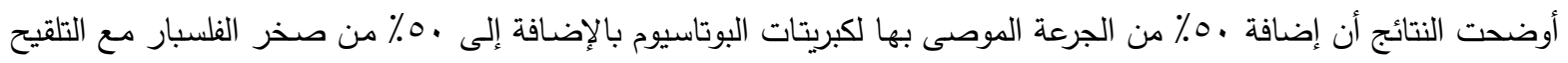

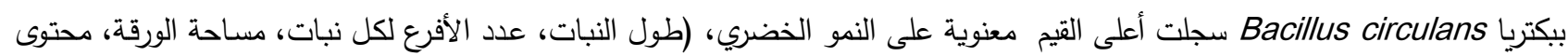

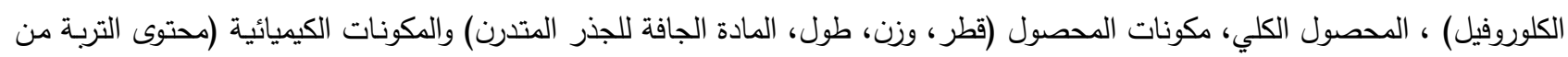

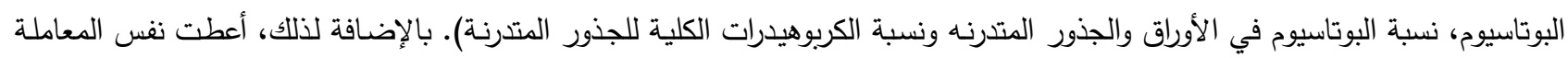

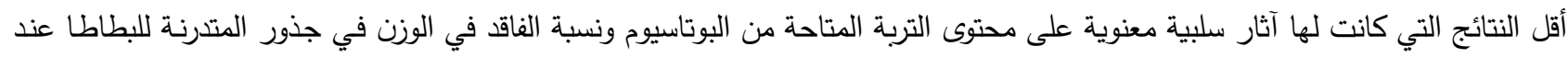

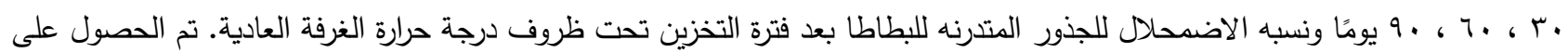

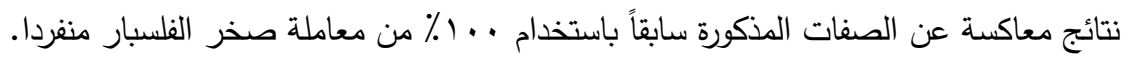
التوصية

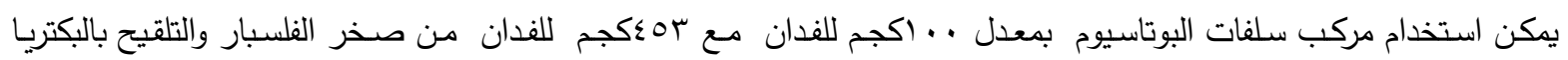
المحررة للبوتاسيوم فى حقول البطاطا لتحسين صفات النمو الخضرى ومكونات المحصول والجودة والتركيب الكمياوى وقدرتة التخزينية بالمقارنة بسماد البوتاسيوم التجارى وكذلك تعظيم الاستفادة من الموارد الطبيعية المتاحة فى البيئة المصرية وتقليل التأثير البيئى للأسمدة الكمياوية.

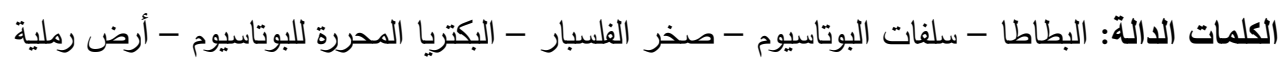

